\title{
EDITORIAL: SEA DRAGONS
}

\author{
Jacek Zaucha (iD 1 , Joanna Pardus ${ }^{2}$ \\ ${ }^{1}$ Faculty of Economics, University of Gdańsk \\ Armii Krajowej 119, 81-824 Sopot: Poland \\ Institute for Development \\ Czyżewskiego 6/1, 81-706 Sopot: Poland \\ jacek.zaucha@ug.edu.pl \\ ${ }^{2}$ Maritime Institute, Gdynia Maritime University \\ Długi Targ 41/42, 80-830 Gdańsk: Poland \\ Institute for Development \\ Czyżewskiego 6/1, 81-706 Sopot: Poland \\ joanna.pardus@im.umg.edu.pl
}

\begin{abstract}
This Editorial provides a framework for the entire volume of Europa XXI devoted to spatial development at sea and at the land-sea interface. It explains why conscious management of marine space is necessary, the benefits that it might provide, and the governance regimes that can be used. It discusses and compares maritime spatial planning and integrated coastal management as means of securing spatial order at sea and at the land-sea interface. Finally, it links together the remaining articles by explaining their added value in relation to one another; and their mutual relations.
\end{abstract}

Keywords: maritime space, maritime spatial development, maritime spatial planning, spatial order at sea and on the coast.

The ancient scientist used the expression hic sunt leones or hic sunt dracones ('here be dragons') to describe regions that had not been mapped or documented. And surprisingly in the traditional domain of spatial planning and development it has also been realised recently that new terra incognita has emerged unnoticed. But this time it is true that 'spatial dragons' are actually present on the sea, so those studying space should extend their research apparatus to understand them, and describe their habits. Spatial sciences face a new challenge - or opportunity - in that they must explain patterns and mechanisms of spatial development at sea. This volume should thus be seen as an attempt to examine the newly-emerged 'spatial dragon' referred to, i.e. the spatial patterns present today at sea, and at the land-sea interface ${ }^{1}-$ i.e. in coastal waters and along the coastal strip (as the terrestrial part of the interface).

The patterns in question were noted first by practitioners; and only subsequently by researchers (Zaucha et al., 2020). The discovery resulted in the development of new management concepts, i.e. Integrated Coastal Zone Management - ICZM (appearing at the end of the $20^{\text {th }}$ century) and maritime spatial planning - MSP (becoming popular at the beginning of this century). The origin and history of both of these is well described in the literature (e.g. Ehler, Zaucha, \& Gee, 2019; Kidd, Shaw, \& Janssen, 2019). The two distinctive features in each case are a focus on an integrated approach and an origin in market failure ${ }^{2}$.

\footnotetext{
${ }^{1}$ For the model describing performance at the land-sea interface, see Zaucha et al. (2016).

${ }^{2}$ Market allocation of goods and services will not provide for the desired or optimal satisfaction of human needs.
} 
Godschalk (2010) explains that, in line with the European Commission's conceptualisation, the essence of the ICZM lies in the promotion of sustainable development of the coastal zone, thanks to a multidisciplinary and iterative process that extends to stock-taking, planning and decision-making, as well as implementation, monitoring and evaluation. ICZM usually has a long time-horizon, and is based on an axiological layer supplied through political or social agreement as to goals and objectives important for a given coastal society. ICZM covers both the seaward and landward parts of the coastal zone; and in some EU sea basins, such as that of the Mediterranean Sea (Ramieri, Bocci, \& Markovic, 2019), it has become a key governance regime relating to both marine waters and the adjacent land.

MSP is also - or should also be - based on a similar layer of shared values and social objectives, albeit with a difference in that the usual focus is on the planning and allocation of maritime space, which is to say a slightly narrower scope than with ICZM, which covers a broader band of various management activities. Moreover, MSP usually extends to the whole of maritime space, and not merely to the coastal belt. Both ICZM and MSP has been tackled at EU level. However, while ICZM was addressed by way of EU recommendations (EC, 2002), the fact that these were well-received did not (in the main) translate into further-reaching implementation in EU member states (not least Poland). In contrast, MSP - as the subject of an EU Directive (EC, 2014) became binding in character.

The original intention had in fact been for the Directive to cover both MSP and ICZM (EC, 2013), but the scope was ultimately reduced to MSP only, as discussions among member states proceeded. The Directive requires that maritime spatial plans be drawn up by all coastal member states of the EU by March 2021, but is typical in leaving the precise planning methodology as a matter for the discretion of planning authorities on various geographical scales (typically in fact the national).

The shift from ICZM to MSP at EU level can be explained by the spillover of spatial conflicts from coast to sea, with intensification occurring even far from land. However, another reason might be the cohesive nature of the sea, given that it forms a single integrated ecosystem that requires an integrated approach if market failures are to be addressed. The EU definition of MSP refers to a "process through which appropriate organs of member states analyse and organise human activity in sea areas in order to achieve ecological, economic and social objectives" (EC, 2014, p.140). Although slightly narrow, given the confinement to action taken by public authorities, this definition highlights the need for various non-market benefits (that cannot been revealed through the market) to be considered as maritime space is developed. "As many marine goods and services are not priced in the market, conflicts often cannot be resolved through economic analysis alone" (Ehler et al., 2019, p.5).

Thus, as the same authors (Ehler et al., 2019, p.8) point out, MSP can be seen as a process aggregating individual human preferences in relation to marine space, using the public-choice framework $^{3}$. The outcome might take various forms, such as a binding regulatory plan, spatial studies, spatial visions or spatial strategies - to name just the most important examples. All of these are integrated in character, in that they pay attention to both pecuniary and non-pecuniary benefits the sea has to offer.

ICZM and MSP are thus important mechanisms securing benefits that cannot be delivered solely by the market. Ehler and Douvere (2009, p.21) emphasise benefits for the natural environment accruing from MSP, as well as those of an economic or social nature. Prominent among these is respect for cultural and spiritual values, appreciation of the effects of synergy, openness to future users of sea areas, a raising of the level of safety of human activity on the sea and - typi-

\footnotetext{
${ }^{3}$ Public choice is that part of public economics focusing on decision-making by public authorities using various legal and fiscal instruments (e.g. legal acts, taxes and subsidies, non-binding recommendations, information disclosure, voluntary coordination, etc.).
} 
cally - a lowering of the scale of conflicts and increase in the degree of predictability for investors. In one of its first studies on this subject (EC, 2006), the European Commission justified integrated maritime policy by reference to the benefits arising out of the conscious management of conflicts over the longer term - given the way this allows such global challenges as climate change to be reacted to. In another document (EC, 2011, p.7), the Commission identified a catalogue of economic non-pecuniary externalities related to the integrated approach, including enhanced coordination and simplified decision processes, enhanced legal certainty for all stakeholders, enhanced cross-border cooperation and enhanced cohesion vis-à-vis other planning systems.

All of the above should translate into an improved investment climate, reduced transaction costs, and a lowering of administration's operating costs. Proposals from Acker and Hodgson $(2008$, p.5) - focused on better management - concern a similar direction, i.e. the quelling of conflicts between diverse interests, a simplification of the process whereby permits and concessions are issued (given that account is taken of their cross-border nature and specific legal status), and the devising of a transparent and predictable mechanism for decision-making that provides for the efficient coordination and integration of sectoral interests, including environmental protection. Payne, Tindall, Hodgson and Harris (2011, p.29) also highlight the significant benefits (including reduced risk of conflict and easier implementation of plans) that are taken to arise as stakeholders participate more fully in the planning process.

On the other hand, spatial planners themselves perceived benefits resulting from an integrated approach in a broader perspective related, not only to the efficiency of development of maritime space, but also to its axiological layer. Thus VASAB anticipates spatial planning of sea areas allowing for a balancing of interests among stakeholders when it comes to the utilisation of maritime space (mitigation of existing conflicts and avoidance of future ones), the safeguarding of the sustainable use of marine resources, protection of the Baltic environment and its natural biodiversity, the prevention of a further deterioration in the ecological state of Baltic waters, facilitated adjustment of maritime space to global phenomena such as climate change, and the ensuring of cohesion and mutual compliance where the management of respective sea areas is concerned (Zaucha, 2008, p.5).

Similarly, the PLANCOAST project (Schultz-Zehden, Gee, \& Ścibior, 2008, p.21) offers a very broad description of the benefits arising from MSP. Planning is taken as allowing for better coordination of the use made of maritime space (including as synergy is achieved), while also providing for a more comprehensive image of existing and planned ways in which benefits can be obtained from marine and coastal areas. In addition, it increases the level of security of the investment process, as it takes account of what might happen in the future; not merely the current state (given the proactive, rather than retroactive, nature of planning). Planning also facilitates just access to marine resources, while strengthening the cohesion of decision-making processes and the acceptance of solutions by stakeholders.

All the benefits in question build - or contribute to the establishment of - the spatial order at sea and on the coast. Spatial order is actually among the so-called 'wicked' problems, in that it is difficult or impossible to solve, given contradictory understanding among different groups in society and stakeholders. On top of that, there is a problem with including the interests of future generations that cannot be identified and are often difficult to recognise.

For the above reasons, spatial order must be redefined continuously and re-established in the course of public-choice discourse. However, we can assume that, in the short run it can be taken as a given. In short, an order of this kind means the maintenance of key unique properties of maritime and coastal space, the prevention or mitigation of spatial conflicts, and (where conflicts are unavoidable), the selection of the solutions most beneficial to a given society in line with shared 
values and norms. Spatial order is among the social institutions as conceived of in broad terms, and should be seen as an ultimate goal of spatial development, both at sea and along the coastal strip.

The latter spatial development can further be defined as a process imbuing spatial order through the interplay between the private and public sectors (Fig. 1). MSP and ICZM provide various public-choice frameworks (regimes) that are useful in this regard. Both form part of spatial policy that reveals, expresses and pushes forward public interest, in the direction of the aforesaid areas. Such policy shapes this development (land use), understood as the functional dimension or socio-economic and ecological use of a given space or its parts (see EC, 2007, Annex III). In this context, spatial development is constituted by the way in which a person uses (or resigns from using) maritime space or the coastal strip; or - alternatively - as the functions of that space or strip.

The concept of policy is usually associated with public authorities acting on behalf of the general public. But here the meaning is broader, in the sense that policy can also be based on agreement between social groups, or be by reference to norms and beliefs shared voluntarily in a given society. Policy can be implemented, not only by legal acts, but also by way of the release of information or conscious efforts at education. However, to achieve spatial order two mechanisms are essential. The first one is what Figure 1 terms spatial dialogue, and that means the joint establishment of key targets and ambitions with regard to spatial development of marine areas and the coastal strip, by private, public and also non-governmental entities. All partners should participate in this process on an equal footing. ICZM and MSP provide a perfect basis for this, but other frameworks can also be envisaged. The second mechanism is a policy adjustment which is a learning process related to conscious and continuous reflection on the effects of policy in changing conditions, with the resultant adaptation of policy to new circumstances and challenges. The learning process should also be opened up to private and non-governmental entities. A lack, or a weakening, of these two elements might lead to policy capture, i.e. a process of the consistent or repeated directing of public-policy decisions away from the public interest in the direction of a specific interest group or person (OECD, 2017, p.9).

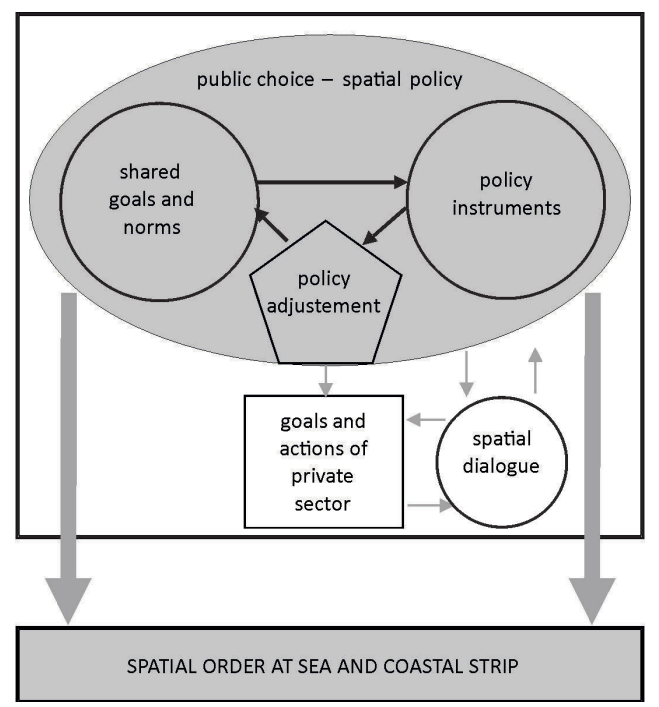

Figure 1. Spatial development at sea and in the coastal strip Source: adapted from Zaucha (2018, p.345). 
As Figure 2 shows, capture of the above kind might result in spatial disorder, as is in fact frequently the case along a Polish coastal strip that is developed in line with a dominating interest of the mass-tourism sector. In general, spatial disorder is characteristic of spatial underdevelopment.

Mechanisms presented in Figures 1 and 2 are universal in character, and can thus exist at sea or along the coastal strip, but also on land, e.g. in rural, urban, mountainous, peripheral or border areas. What is characteristic for the land-sea interface and for maritime space is a sea-specific set of public values and goals (e.g. related to marine or costal ecosystems or landscapes), unique natural, social and economic conditions for development, and a distinctive set of marine externalities and therefore specific knowledge that should inform spatial policies in these areas.

This volume will be related to these specific aspects. It aims to bring together various pieces of the puzzle named spatial development of the sea and the coastal strip, with a view to the reader being provided with the building blocks necessary to understand how those areas have been developing, and/or should be developed.

This volume is consciously devoted to themes that have not gained such extensive discussion in the spatial planning literature, but have recently been giving rise to new results. The selection of papers will not therefore offer a full picture when it comes to various theoretical approaches explaining the emergence of new spatial patterns at sea, as well as the land-sea interface. For instance, certain attempts at the explanation of the latter - by reference to spatial economics - have come to the attention of the scientific community thanks to Schultz-Zehden, Weig and Lukic (2019), Zaucha (2019), and Zaucha et al. (2020), or whereas an approach based in the social sciences has been espoused by Flannery, Clarke and McAteer (2019), McKinley, Acott and Stojanovic (2019), and Saunders, Gilek and Tafon (2019). The legal sciences have also injected interesting input into the discourse (Maes, 2008; Pyć, 2019). Those interested in these findings may seek necessary answers or inspiration from the body of literature referred to above.

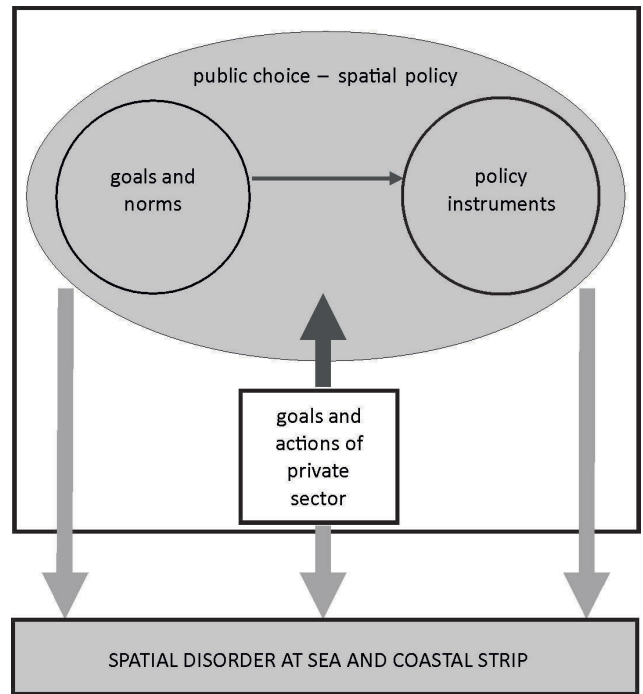

Figure 2. Spatial underdevelopment at sea and in the coastal strip Source: adapted from Zaucha (2018, p.346). 
Equally, this volume is able to complement some pieces of research already in existence, by highlighting such novel issues as emotional bonds to the sea, the specific situation of small oceanic islands in exploiting sea-related benefits, land-sea interactions in general and from an urban perspective in particular, and the importance of aesthetic values as maritime space and the land-sea interface are under development.

Jerzak et al. (2019) open the proceedings here, providing a definition of maritime space and offering certain new, if mutually compatible perspectives in respect of relevant research and the understanding of the role played. This should be seen as complementing the existing interdisciplinary monograph edited by Zaucha and Gee (2019), whose main focuses are on the spatial, social and ecological sciences. Jerzak et al. (2019) add two new dimensions, of which the first is literature research in which the sea is analysed from the perspective of human existence, human wonders, and emotions relating to maritime space. The latter is taken as inspiring, creating new ideas, and shaping human character and attitudes. A second dimension explores harmony at the land-sea interface, from the perspective of architects and urban planners. Their work explores the functionality between land and sea. The dimensions analysed by Jerzak et al. acknowledge human beings as a constituting factor underpinning the development of maritime space, with continuous redefining and re-engineering of that space, its content and dynamics taking place. Therefore, as they dwell on Zaucha (2018), Jerzak et al. propose that maritime space be understood as constituted by position, distance, and the relationships between the natural environment of the sea, human investments, and the activities taking place at sea, by way of flows and interactions between them.

Gee and Siedschlag (2019) go even further by applying a constructivist and relational understanding to maritime space, which they conceptualise as in a constant state of redefinition and redevelopment (such that the act of 'place-making' can be taken to express mutually constituting interactions and relationships between people and places). The 'place-making' referred to imbues with meaning the seat assigned to objects and experiences on the basis of individual perception, action, and different ways of knowing the sea. A key role is played by culture, social values and norms, but also by the private experiences of various 'clients' of the sea - in particular as regards the benefits and emotions obtained from or thanks to it.

Such a place-based perspective of interpreting maritime space assumes that places are never actually abstract or distant, but forever characterised by the emotions they give rise to. The latter are then an inherent part of the creative process by which places are made. In consequence, the authors suggest opening MSP up to "continuous dialogue surrounding options and spheres of possibility, as well as existing and changing practices of place-making" (p.70). MSP should thus pay attention, not only to the values ascribed to marine places, but also to the processes essential in their creation.

This emotional bond with the sea, along with the processes that link it with human beings, is surely important to those who live on oceanic archipelagos. Yet Calado et al. (2019) take a quite different perspective as they presents the geographical shaping of uses made of maritime space in Macaronesia (as the biogeographical region comprising the Azores, Madeira, the Selvagens, and the Canary and Cape Verde Islands). The entirely novel issues explored here link the exploitation of marine space with the development of small and remote oceanic islands on which human and natural resources are limited, while autonomy as regards governance is enjoyed in many cases. It is typical for the islands in question to be surrounded by vast sea areas (mostly far larger than the actual country), with both considerable economic potentials and high ecological value. As Calado et al. point out, islands of this kind link strongly with the ocean and its resources (on which they are very much dependent for sustenance, income and cultural identify). They might thus assume 
a new role as conceptual leaders shaping the spatial development of their marine surroundings. While MSP might offer these islands the benefits of careful and integrated development, it might also challenge small island communities, in terms of their being able to muster the knowledge and experience necessary for MSP.

Kidd et al. offer a smooth passage from sea to land, discussing the history of ICZM and MSP in the context of land-sea interactions (LSI), which they view as fundamental to human wellbeing. In line with what they ascribe to the definition of maritime space from Jerzak et al. - in regard to flows and interconnections - Kidd et al. (2019) underline the need for an integrated approach to the management of the interactions referred to. Such integration might cover 'inter-sectoral integration' (amongst different coastal sectors), 'intergovernmental integration' (amongst levels of government), 'spatial integration' (between various types of area), 'international integration' (dealing with transboundary issues), and 'science-management integration'.

An original MSP-LSI (land-sea interaction) framework is then proposed, by which to consider LSI in MSP, and to explore LSI in different contexts. A new method for researching LSI in various real-life circumstances is also put forward, with this comprising scoping (work with stakeholders), value chain analysis, governance analysis and the formulation of recommendations. The middle part is very interesting, given the way in which the value chain offers an integrated picture of the 'spatialised' impact of the business sector. The governance analysis in turn allows the problem of fragmentation of governance at a land-sea interface to be coped with. The method developed by the authors is offered as a supplement to traditional sea-oriented MSP, which treated LSI as an external factor originating on land, and usually then beyond MSP jurisdiction. In their conclusion, the authors argue for a more entrepreneurial form of MSP, and for spatial planning under which land and sea are subject to the same territorial planning regime.

For their part, Orłowski and Szczerbicki (2019) discuss the concept of smart blue cities, with a focus on LSI interactions originating at sea (and hence on the way in which a maritime location influences the path to smart development taken by large coastal urban areas). They identify issues providing for linkage between the smart and blue city growth concepts, i.e. blue mobility (like autonomous public transport by water), smart living (like the utilisation of water by high quality housing) and the smart economy (like the development of bases for new offshore economic activities). The authors have not managed to identify genuine blue smart cities in Poland, as such cities do not yet exist. Candidates might be Szczecin, Gdynia and Gdańsk, as cities striving to implement smart ideas that pay attention to their coastal location. However, in the view of the authors, more intensive coordination between the smart and blue development components in these cities is still necessary, and should not be limited to the facilitation of a technology-oriented approach, since an equal challenge lies in the social dimension to making blue cities smart (e.g. with smart tourism enhances, at the expense of the mass tourism that spoils the lives of permanent residents and may even drive them out).

In her work, Krośnicka (2019) also adheres to the local level of analysis in her discussion of port development. She notes how many ports have started to develop seaward, showing an eagerness to bring extensive sea areas under their exclusive possession, even displacing certain other traditional maritime uses as they do so. Indeed, as the author notes, port infrastructure may be expanding both landward and out to sea at the same time. Not only are trans-shipment functions performed on new land built out on to water, but logistics and industrial activity, as well as that connected with energy generation, are also moving out into former marine areas.

This all means that port development is no longer subject solely to terrestrial spatial planning, but must be also taken into consideration within the MSP framework. Needless to say, the 
author also voices a certain legitimate concern regarding the environmental consequences of the expansion she seeks to document. A new task for MSP will therefore need to be the securing of necessary environmental compensation that makes amends for the impact port developments exert. This is then an entirely novel issue for MSP, that is not addressed properly in existing maritime spatial plans for the Baltic Sea region. Finally, the author opts for ICZM as a plausible way in which land and sea development can be better coordinated and reconciled.

To finish up, Faludi (2019) offers a further, much-needed link between marine and terrestrial space, in a crème de la crème article with very deeply argued thoughts as to how the development of maritime space should inspire its terrestrial counterpart. The approach is an entirely fresh and new one, but Faludi is right. Maritime space teaches us how various limitations may be overcome, and Faludi argues for a functional approach that pays attention to the genuine interactions constituting the space in which we live. His paper raises concerns of importance for spatial planning both maritime and terrestrial. Boundaries have had to be redefined, with the effect being fuller differentiation; while attention now needs to be paid to functional, political and institutional space. The author amasses several arguments against territorialism within precisely-demarcated areas under the control of public authorities, holding that this generates the 'false consciousness' which holds that 'taking back control' of one's territory is the solution to today's problems. On the contrary, Faludi asserts, it is flexible, issue-based and spatially overlapping governance arrangements that may be in a better position to address the complexity characterising modern European space both at sea and land.

This brief presentation of the papers published in this volume can only encourage a conclusion to the effect that spatial development at sea - and the sea-land interface - benefits from non-standard multi-sectoral and multi-disciplinary investigation. The ocean perspective is an extremely complex one, as we see when we juxtapose the chapter headings in the seminal paper by Gee (2019), which discusses the essence of maritime space and its role in human history in terms of: grasping the ungraspable, mare liberum and mare clausum, enclosure, place of attachment and the non-utilitarian perspective. Each of these themes might be worth a monograph in its own right, but this volume also shows how even this broad array of research themes leaves many new, untouched or hardly-touched fields where maritime space is concerned. Indeed, even the uncertainty as regards the essence of that space remains unresolved. Still, even at this initial stage, we should join Jerzak et al. (2019) in expressing our admiration and respect for marine space; while also recognising the rectitude of Kidd et al. (2019), as they acknowledge the importance of the human dimension, as we seek to understand spatial development, both at sea and on the adjacent land.

\section{Acknowledgment}

This volume has been compiled thanks to scientific debate taking place in Sopot on $23^{\text {rd }}-24^{\text {th }}$ September 2019. The conference in question was initiated by two Task Forces of the Committee for the Spatial Economy and Regional Planning of the Polish Academy of Sciences, i.e. the Task Force for urban and metropolitan areas and the Task Force for integrated development policy for Europe and Poland. The event was attended by more than 70 academics from Poland, as well as guests and speakers from various EU countries. Its main aim was to present the results of a project entitled "The economy of maritime (sea) space" that had been financed by the Polish National Science Centre in line with decision 2015/17/B/HS4/00918. The conference gave rise to many new and 
interesting discussions and debates ultimately bearing fruit in this volume of Europa XXI, in line with participants' realisation of the fact that they were indeed approaching a new 'spatial dragon' in need of more decent attention and recognition.

\section{References}

Acker, H., \& Hodgson, S. (2008). European Commission Legal Aspects of Maritime Spatial Planning. Final Report to DG Maritime Affairs \& Fisheries. MRAG, Framework Service Contract, No. FISH/2006/09 LOT2. Retrieved on December 5, 2020 retrieved from https://www.msp-platform.eu/sites/default/ files/legal_aspects_msp_report_en.pdf

Calado, H., Caña Varona, M., Suarez de Vivero, J. L., Moniz, F., Halim, F., Gabriel, D., Hipólito, C., Menini, E., Kramel, D., Vergílio, M., \& Ferreira, M. A. (2019). Island geography shaping maritime space in Macaronesia. Europa XXI, 36, - . https://doi.org/10.7163/Eu21.2019.36.8

EC (2002). Recommendation of the European Parliament and of the Council of 30 May 2002 concerning the implementation of Integrated Coastal Zone Management in Europe (2002/413/EC). Official Journal of the European Communities L 148/24.

EC (2006). Green Paper Towards a future Maritime Policy for the Union: A European vision for the oceans and seas. $\operatorname{COM(2006),~} 275$ final, Volume II, Brussels.

EC (2007). Directive 2007/2/EC of the European Parliament and of the Council of 14 March 2007 establishing an Infrastructure for Spatial Information in the European Community (INSPIRE). L 108/13.

EC (2011). Study on the economic effects of Maritime Spatial Planning. Luxembourg: Publications Office of the European Union.

EC (2013). Proposal for a Directive of the European Parliament and of the Council establishing a framework for maritime spatial planning and integrated coastal management. Brussels, 12.3.2013, $\operatorname{COM}(2013), 133$ final.

EC (2014). Directive 2014/89/EU of the European Parliament and of the Council of 23 July 2014 establishing a framework for maritime spatial planning. Official Journal of the European Union, L 257/135.

Ehler, C., Zaucha, J., \& Gee, K. (2019). Maritime Spatial Planning at the Interface of Research and Practice. In: J., Zaucha \& K., Gee (Eds.). Maritime Spatial Planning, Past, Present, Future (pp. 1-21). London, Cham: Palgrave. https://doi.org/10.1007/978-3-319-98696-8_1

Ehler, C., \& Douvere, F. (2009). Maritime Spatial Planning. A Step-by Step Approach. Toward Ecosystem Based Management. UNESCO IOC Manual and Guides, 153, Paris.

Faludi, A. (2019). New horizons: Beyond territorialism. Europa XXI, 36, 35-44. https://doi.org/10.7163/ Eu21.2019.36.3

Flannery, W., Clarke, J., \& McAteer, B. (2019). Politics and Power in Marine Spatial Planning. In: J., Zaucha \& K., Gee (Eds.). Maritime Spatial Planning, Past, Present, Future (pp. 201-217). London, Cham: Palgrave. https://doi.org/10.1007/978-3-319-98696-8_9

Gee, K. (2019). The Ocean Perspective. In: J., Zaucha \& K., Gee (Eds.). Maritime Spatial Planning, Past, Present, Future (pp. 23-45). London, Cham: Palgrave. https://doi.org/10.1007/978-3-319-98696-8_2

Gee, K., \& Siedschlag, D. (2019). A place-based perspective on marine and coastal space. Europa XXI, 36, 59-74. http://doi.org/10.7163/Eu21.2019.36.6

Godschalk, D. R. (2010). Coastal Zone Management. In: P., Hoagland (Ed.). Marine Policy \& Economics (pp. 44-50). London: Elsevier.

Jerzak, K., Shrayer, M.D., Krośnicka, K.A., Lorens, P., Zaucha, J., \& Pardus, J. (2019). The essence of marine and coastal space - an interdisciplinary perspective. Europa XXI, 36, 15-34. https://doi.org/10.7163/ Eu21.2019.36.2

Kidd, S., Shaw, D., \& Janssen, H. (2019). Exploring land-sea interactions: Insights for shaping territorial space. Europa XXI, 36, 45-58. https://doi.org/10.7163/Eu21.2019.36.5

Krośnicka, K. A. (2019). Container port expansion towards the sea in the context of maritime spatial planning. Europa XXI, 36, - . https://doi.org/10.7163/Eu21.2019.36.9

Maes, F. (2008). The international legal framework for marine spatial planning. Marine Policy, 32, 797810. https://doi.org/10.1016/j.marpol.2008.03.013 
McKinley, E., Acott, T., \& Stojanovic, T. (2019). Socio-cultural Dimensions of Marine Spatial Planning. In: J., Zaucha \& K., Gee (Eds.). Maritime Spatial Planning, Past, Present, Future (pp. 151-174). London, Cham: Palgrave. https://doi.org/10.1007/978-3-319-98696-8_7

OECD (2017). Preventing Policy Capture. Integrity in Public Decision Making. Paris: OECD Publishing. https://dx.doi.org/10.1787/9789264065239-en

Orłowski, A., \& Szczerbicki, E. (2019). Smart Blue Cities. Europa XXI, 36, - . https://doi.org/10.7163/ Eu21.2019.36.7

Payne, I., Tindall, C., Hodgson, S., \& Harris, C. (2011). Comparison of national Maritime Spatial Planning (MSP) regimes across EU. In: Seanergy 2020. Comparative analysis of Maritime Spatial Planning (MSP) regimes, barriers and obstacles, good practices and national policy recommendations. Retrieved on December 9, 2019 https://ec.europa.eu/energy/intelligent/projects/sites/iee-projects/ files/projects/documents/seanergy_2020_comparative_analysis_of_msp_regimes_en.pdf

Pyć, D. (2019). The Role of the Law of the Sea in Marine Spatial Planning. In: J., Zaucha \& K., Gee (Eds.). Maritime Spatial Planning, Past, Present, Future (pp. 375-395). London, Cham: Palgrave. https://doi. org/10.1007/978-3-319-98696-8_16

Ramieri, E., Bocci, M., \& Markovic,, M. (2019). Linking Integrated Coastal Zone Management to Maritime Spatial Planning: The Mediterranean Experience. In: J., Zaucha \& K., Gee (Eds.). Maritime Spatial Planning, Past, Present, Future (pp. 271-294). London, Cham: Palgrave. https://doi.org/10.1007/9783-319-98696-8_12

Saunders, F. P., Gilek, M., \& Tafon, R. (2019). Adding People to the Sea: Conceptualizing Social Sustainability in Maritime Spatial Planning. In: J., Zaucha \& K., Gee (Eds.). Maritime Spatial Planning, Past, Present, Future (pp. 175-199). London, Cham: Palgrave. https://doi.org/10.1007/978-3-319-986968_8

Schultz-Zehden, A., Gee, K., \& Ścibior, K. (2008). Handbook on Integrated Maritime Spatial Planning. Berlin: S.Pro.

Schultz-Zehden, A., Weig, B., \& Lukic, I.(2019). Maritime Spatial Planning and the EU's Blue Growth Policy: Past, Present and Future Perspectives. In: J., Zaucha \& K., Gee (Eds.). Maritime Spatial Planning, Past, Present, Future (pp. 121-149). London, Cham: Palgrave. https://doi.org/10.1007/978-3-31998696-8_6

Zaucha, J. (2008). Sea Use Planning and ICZM Input to the Long Term Spatial Development Perspective. Final report from Working Group 3. Riga: Vision and Strategies around the Baltic. Retrieved on December 15, 2019 from https://vasab.org/east-west-window/documents/

Zaucha, J. (2018). Gospodarowanie przestrzenią morską. Warszawa: Sedno.

Zaucha, J. (2019). Can Classical Location Theory Apply to Sea Space? In: J., Zaucha \& K., Gee (Eds.). Maritime Spatial Planning, Past, Present, Future (pp. 97-119). London, Cham: Palgrave. https://doi. org/10.1007/978-3-319-98696-8_5

Zaucha, J., Davoudi, S., Slob, A., Bouma, G., van Meerkerk, I., Oen, A. M., \& Breedveld, G. D. (2016). State-of-the-lagoon reports as vehicles of cross-disciplinary integration. Integrated Environmental Assessment and Management, 12(4), 690-700. https://doi.org/10.1002/ieam.1802

Zaucha, J., \& Gee, K. (Eds.). (2019). Maritime Spatial Planning, Past, Present, Future. London, Cham: Palgrave.

Zaucha, J., Matczak, M., Witkowska, J., Szczęch, A., Mytlewski, A., \& Pardus, J. (2020). Maritime spatial rent for modelling maritime spatial development. Studia Regionalne i Lokalne, 1 (in print).

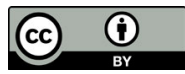

